\title{
Penggunaan Modul Fisika SMA/MA dan SMK Berbasis Inkuiri yang Disertai Penilaian Portofolio Dilihat dari Praktikalitas
}

\author{
Iing Rika Yanti \\ Pendidikan Fisika STKIP PGRI Sumatera Barat \\ e-mail: iing1408@gmail.com \\ http://dx.doi.org/10.22202/irfes.2015.v2i1.1912
}

\section{Abstract}

High school physics is one of the subjects Physics Education in STKIP PGRI West Sumatra. Teaching materials developed is an inquiry-based module that is able to make the students more active, creative and critical thinking as well as skilled in the discovery of the facts in High School Physics. In addition to teaching materials Lecturers are also expected to carry out an assessment based on class one portfolio assessment This research is the development (research and development) using a model of Plomp is passing through stages: (1) the initial investigation (preliminary research), (2) design and realization (prototyping phase), and (3) testing and assessment (assessment phase) .In this paper focuses the discussion of the practicalities of researchers are at the stage of prototyping phase. The research data was obtained through a questionnaire sheet practicalities. Based on the results of questionnaire analysis practicality of lecturers obtained categorized module is very practical, it is seen from the percentage of faculty responses to the module is $84.1 \%$. indicates that the module has been developed practical use in learning.

Keywords : Physics SMA / MA and SMK Module, Inquiry, Portfolio Assessment, the practicalities

\begin{abstract}
Abstrak
Fisika SMA/MA dan SMK merupakan salah satu mata kuliah Program Studi Pendidikan Fisika di STKIP PGRI Sumatera Barat. Bahan ajar yang dikembangkan merupakan modul yang berbasis inkuiri mampu untuk membuat siswa lebih aktif, kreatif, dan berfikir secara kritis serta terampil dalam penemuan fakta-fakta dalam Fisika SMA/MA dan SMK. Selain bahan ajar Dosen juga diharapkan melaksanakan penilaian berbasis kelas salah satunya penilaian portofolio Penelitian ini merupakan penelitian pengembangan (research and development) menggunakan model Plomp yaitu yang melewati tahapan: (1) investigasi awal (preliminary research), (2) perancangan dan realisasi (prototyping phase), dan (3) uji coba dan penilaian (assessment phase).Pada jurnal ini focus pembahasan peneliti adalah praktikalitas pada tahapan prototyping phase. Data penelitian ini diperoleh melalui lembar angket praktikalitas. Berdasarkan hasil analisis angket kepraktisan dari dosen didapatkan modul berkategori sangat praktis, hal ini terlihat dari persentase tanggapan dosen terhadap modul adalah $84,1 \%$. menunjukkan bahwa modul yang telah dikembangkan praktis digunakan dalam pembelajaran.
\end{abstract}

Kata kunci Modul Fisika SMA/MA dan SMK, Inkuiri, Penilaian Portofolio, Praktikalitas 


\section{PENDAHULUAN}

Fisika merupakan bagian dari ilmu sains yang mempelajari gejala dan fenomena alam serta mengungkap rahasia alam semesta secara ilmiah. Fisika berhubungan erat dengan perkembangan teknologi. Berbagai produk teknologi mutakhir yang berkembang saat ini didominasi oleh ilmu fisika. Prinsipprinsip fisika merupakan basis terciptanya alat-alat teknologi tersebut. Mengingat begitu berperannya ilmu fisika bagi manusia, sehingga kualitas pembelajaran fisika harus ditingkatkan. Salah satu mata kuliah Program Studi Pendidikan Fisika adalah Fisika SMA/MA dan SMK yang mampu menunbuhkan pola pikir kritis mahasiswa dalam merumuskan sendiri penemuannya yang berkaitan dengan pembelajaran yang diberikan. Oleh sebab itu, penguasaan Fisika SMA/MA dan SMK haruslah memadai.

Kenyataan yang terjadi di lapangan hasil belajar Fisika SMA/MA dan SMK mahasiswa masih rendah. Rendahnya hasil belajar mahasiswa yang terdapat di lapangan disebabkan oleh beberapa hal, yaitu dalam proses pembelajaran, mahasiswa belum dilibatkan secara aktif dalam memecahkan masalah-masalah dalam kehidupan sehari-hari. Di lain pihak, mahasiswa yang telah memahami konsep Fisika SMA/MA dan SMK belum mampu berpikir kritis sehingga dapat menerapkan konsep itu di dalam kehidupan mereka sehari-hari. Serta bahan ajar yang dirancang dosen belum sesuai dengan keadaan mahasiswa serta karakteristik kampusnya.

Pembelajaran Fisika sangat erat dengan model inkuiri. Hal ini disebabkan model pembelajaran inkuiri tidak hanya mengembangkan kemampuan intelektual tetapi seluruh potensi yang ada, termasuk pengembangan emosional dan merupakan proses yang bermula dari masalah, merumuskan masalah, merumuskan hipotesis, mengumpulkan data, menganalisis data dan membuat kesimpulan. Model inkuiri merupakan suatu rangkaian kegiatan belajar yang melibatkan secara maksimal seluruh kemampuan mahasiswa untuk mencari dan menyelidiki secara sistematis, kritis, logis, analitis, sehingga mereka dapat merumuskan sendiri penemuannya.

Pembelajaran inkuiri berarti suatu rangkaian kegiatan yang melibatkan secara maksimal seluruh kemampuan mahasiswa untuk mencari dan menyelidiki secara sistematis, kritis, logis, analogis sehingga mereka dapat merumuskan sendiri penemuannya. Inkuiri tidak hanya mengembangkan kemampuan intelektual tetapi seluruh potensi yang ada, termasuk pengembangan emosional dan keterampilan Inkuiri. Inkuiri merupakan suatu proses yang bermula dari merumuskan masalah, merumuskan hipotesis, mengumpulkan data, dan 
membuat kesimpulan. Pembelajaran inkuiri dirancang untuk mengajak siswa langsung ke dalam proses ilmiah dalam waktu yang relatif singkat.

Rincian sintaks mengenai pembelajaran inkuiri [3] disajikan pada Tabel 1. Sintaks merupakan gambaran pola kegiatan guru dan siswa dalam berinteraksi diperuntuk mencapai tujuan pembelajaran.

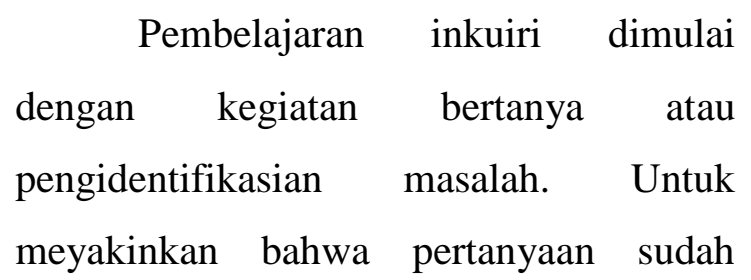

jelas, pertanyaan tersebut di tulis pada papan tulis, kemudian mahasiswa diminta merumuskan hipotesis. Hipotesis adalah jawaban sementara atas pertanyaan atau solusi permasalahan yang dapat diuji dengan data. Hipotesis digunakan untuk menuntun proses pengumpulan data. Mahasiswa bertanggung jawab menguji hipotesis yang telah dirumuskan dengan menganalisa data yang diperoleh. Langkah terakhir adalah membuat kesimpulan.

Tabel 1. Sintaks Pembelajaran Inkuiri

\begin{tabular}{ll}
\hline \multicolumn{1}{c}{ Fase } & \multicolumn{1}{c}{ Kegitan Guru } \\
\hline $\begin{array}{l}\text { Fase 1 } \\
\text { Menyajikan pertanyaan atau } \\
\text { masalah }\end{array}$ & $\begin{array}{l}\text { Guru membimbing siswa mengidentifikasi masalah, } \\
\text { ditulis di papan tulis. Siswa dibentuk dalam kelompok }\end{array}$ \\
$\begin{array}{l}\text { Membuat hipotesis } \\
\text { Guru memberikan kesempatan pada siswa untuk curah } \\
\text { pendapat dalam bentuk hipotesis. Guru membimbing } \\
\text { siswa dalam menentukan hipotesis yang relevan dengan } \\
\text { permasalahan dan memprioritaskan hipotesis mana yang } \\
\text { menjadi prioritas penyelidikan }\end{array}$ \\
$\begin{array}{l}\text { Fase 3 } \\
\text { Mengumpulkan data } \\
\text { Fase 4 } \\
\text { Menganalisis data }\end{array}$ & $\begin{array}{l}\text { Guru memberi kesempatan pada tiap kelompok untuk } \\
\text { Fase 5 }\end{array}$ \\
Membuat kesimpulan & Guru membimbing siswa dalam membuat kesimpulan \\
\hline
\end{tabular}

Berdasarkan sintak inkuiri di atas maka tahap kegiatan dosen dan mahasiswa dapat dikembangkan menjadi :

Tabel 2. Tahap-tahap pembelajaran berbasis inkuiri

\begin{tabular}{|c|c|c|}
\hline $\begin{array}{c}\text { Tahap } \\
\text { pembelajaran }\end{array}$ & Kegiatan Dosen & Kegiatan Mahasiswa \\
\hline $\begin{array}{l}\text { Fase } 1 \\
\text { Menyajikan }\end{array}$ & $\begin{array}{l}\text { Dosen membimbing mahasiswa } \\
\text { mengidentifikasi masalah, ditulis }\end{array}$ & $\begin{array}{l}\text { Mahasiswa mengidentifikasi } \\
\text { masalah, ditulis di papan tulis. }\end{array}$ \\
\hline
\end{tabular}




\begin{tabular}{|c|c|c|}
\hline $\begin{array}{c}\text { Tahap } \\
\text { pembelajaran }\end{array}$ & Kegiatan Dosen & Kegiatan Mahasiswa \\
\hline $\begin{array}{l}\text { pertanyaan atau } \\
\text { masalah } \\
\text { Fase } 2 \\
\text { Membuat } \\
\text { hipotesis }\end{array}$ & $\begin{array}{l}\text { di papan tulis. Mahasiswa } \\
\text { dibentuk dalam kelompok } \\
\text { Dosen memberikan kesempatan } \\
\text { pada mahasiswa untuk curah } \\
\text { pendapat dalam bentuk hipotesis. } \\
\text { Dosen membimbing mahasiswa } \\
\text { dalam menentukan hipotesis yang } \\
\text { relevan dengan permasalahan dan } \\
\text { memprioritaskan hipotesis mana } \\
\text { yang menjadi prioritas } \\
\text { penyelidikan }\end{array}$ & $\begin{array}{l}\text { Mahasiswa dibentuk dalam } \\
\text { kelompok } \\
\text { Mahasiswa curah pendapat } \\
\text { dalam bentuk hipotesis. Dan } \\
\text { mahasiswa dalam menentukan } \\
\text { hipotesis yang relevan dengan } \\
\text { permasalahan dan } \\
\text { memprioritaskan hipotesis } \\
\text { mana yang menjadi prioritas } \\
\text { penyelidikan }\end{array}$ \\
\hline $\begin{array}{l}\text { Fase } 3 \\
\text { Mengumpulkan } \\
\text { data }\end{array}$ & $\begin{array}{l}\text { Dosen membimbing mahasiswa } \\
\text { mendapatkan informasi }\end{array}$ & $\begin{array}{l}\text { Mahasiswa mendapatkan } \\
\text { informasi (data) }\end{array}$ \\
\hline $\begin{array}{l}\text { Fase } 4 \\
\text { Menganalisis data }\end{array}$ & $\begin{array}{l}\text { Dosen memberi kesempatan pada } \\
\text { tiap kelompok untuk } \\
\text { menyampaikan hasil pengolahan } \\
\text { data yang terkumpul }\end{array}$ & $\begin{array}{l}\text { Tiap kelompok menyampaikan } \\
\text { hasil pengolahan data yang } \\
\text { terkumpul }\end{array}$ \\
\hline $\begin{array}{l}\text { Fase } 5 \\
\text { Membuat } \\
\text { kesimpulan }\end{array}$ & $\begin{array}{l}\text { Dosen membimbing mahasiswa } \\
\text { dalam membuat kesimpulan }\end{array}$ & $\begin{array}{l}\text { Mahasiswa membuat } \\
\text { kesimpulan }\end{array}$ \\
\hline
\end{tabular}

Kelebihan perkembangan

inkuiri menurut [4] mereka dapat mengasimilasi dan mengakomodasi informasi. a. Dapat membentuk dan mengembangkan "self-concept" pada diri siswa, sehingga siswa dapat menegrti tentang konsep dasar dan ide-ide lebih baik.

b. Membantu dalam menggunakan ingatan dan transfer pada situasi proses belajar yang baru.

c. Mendorong siswa berpikir intuitif dan merumuskan hipotesisnya sendiri.

d. Memberi kepuasan yang bersifat instrinsik.

e. Dapat mengembangkan bakat atau kecakapan individu.

f. Member kebebasan pada siswa untuk belajar sendiri.

g. Siswa dapat menghindari caracara belajar tradisional.

h. Dapat memberikan waktu pada siswa yang secukupnya sehingga

\section{Penilaian Portofolio}

Dosen mengadakan penilaian untuk membuat keputusan tentang pembelajaran seperti hal apa pembelajaran perlu diperbaiki, mahasiswa mana yang memerlukan tambahan bantuan, seberapa jauh hasil pembelajaran sesuai dengan tujuan yang telah ditentukan. Dengan kata lain, penilaian oleh pihak dosen harus menghasilkan tindakan untuk meningkatkan pembelajaran atau hasil belajar. Agar penilaian dapat 
menghasilkan tindakan untuk meningkatkan pembelajaran, penilaian harus : menghasilkan informasiyang relevan dengan pembelajaran, baik informsi formal maupun informasi. Selain tes tertulis yang lazim dalam penilaian hasil belajar, dosen harus mengadakan penilaian dengan cara lain, salah satunya adalah penilaian portofolio.

Portofolio adalah kumpulan hasil karya mahasiswa, sebagai hasil pelaksanaan tugas kinerja yang ditentukan oleh dosen atau oleh mahasiswa bersama dosen, sebagai bagian dari usaha mencapai tujuan belajar, atau mencapai kompetensi yang ditentukan dalam kurikulum. Instrumen penilaian portofolio difokuskan pada dokumen tentang kerja mahasiswa yang produktif, yaitu bukti tentang sesuatu yang dapat dikerjakan (dijawab atau dipecahkan) oleh mahasiswa [5] menjelaskan bahwa kumpulan informasi tersebut diketahui oleh guru sebagai bahan pertimbangan dalam menentukan langkah-langkah perbaikan pembelajaran, atau peningkatan belajar peserta didik, seperti:

a. Hasil proyek, penyelidikan, atau praktik, yang disajikan secara tertulis. Hal ini terlihat pada penilaian psikomotor, kinerja dan afektif peserta didik.

b. Gambar atau laporan hasil pengamatan c. Analisis situasi yang berkaitan atau relevan

d. Deskripsi dan diagram pemecahan suatu masalah

e. Laporan hasil penyelidikan tentang hubungan antara konsepkonsep

f. Penyelesaian soal-soal

g. Hasil tugas pekerjaan rumah.

$$
\text { Dengan adanya penilaian }
$$
portofolio, setiap tahapan dalam model inkuiri dapat menjadi bahan observasi dosen baik aktivitas maupun karya-karya yang dihasilkan oleh mahasiswa dalam proses pembelajaran.

\section{Modul}

Modul memiliki peranan penting dalam meningkatkan hasil belajar mahasiswa. Struktur yang harus dipenuhi pada modul adalah terdapat standar kompetensi, kompetensi dasar, indikator, tujuan pembelajaran yang hendak dicapai, materi pembelajaran, tugas terstruktur serta referensi yang menjadi sumber bacaan. Penyampaian materi yang singkat dan tepat yang terdapat dalam modul memudahkan mahasiswa untuk memahami dan mengingat materi yang diajarkan.

Modul merupakan suatu unit program pembelajaran yang disusun dalam bentuk tertentu untuk keperluan belajar. Dengan kata lain, modul merupakan suatu paket belajar yang berkenaan dengan satu unit bahan pelajaran. Dari pengertian modul, dapat 
diambil kesimpulan bahwa modul hanya menyajikan satu topik materi bahasan yang merupakan satu unit program pembelajaran tertentu.

Modul merupakan bahan ajar mandiri (cetak atau perangkat lunak/software) yang disusun secara sistematis dan menarik. Modul adalah sebuah buku yang ditulis dengan tujuan agar peserta didik dapat belajar secara mandiri tanpa atau dengan bimbingan guru, sehingga modul berisi paling tidak tentang [6]
a. Petunjuk belajar (Petunjuk peserta didik/guru)
b. Kompetensi yang akan dicapai
c. Content atau isi materi
d. Informasi pendukung
e. Latihan-latihan
f. Petunjuk kerja, dapat berupa Lembar Kerja (LK)
g. Evaluasi
h. Balikan terhadap hasil evaluasi

Bahasa yang digunakan dalam modul sangat sederhana dan komunikatif sesuai dengan perkembangan mahasiswa. Materinya dikemas dalam unit kecil, dilengkapi dengan contoh, ilustrasi, tugas, latihan, rangkuman, penilaian, umpan balik terhadap hasil penilaian, dan rujukan/referensi pendukung materi.

[6] menyatakan dalam menulis bahan ajar khususnya modul terdapat beberapa tahapan yang harus dilalui, yaitu:

1) Analisis SK dan KD
2) Menentukan judul-judul modul

3) Pemberian kode modul

4) Penulisan Modul

Ciri khas modul adalah tersedianya berbagai petunjuk yang lengkap dan rinci, agar mahasiswa mampu menggunakan modul dalam membelajarakan diri mereka sendiri.

Berdasarkan uraian di atas, maka disusunlah modul menggunakan model inkuiri untuk mata kuliah Fisika SMA/MA dan SMK. Modul berbasis inkuiri ini menggunakan sintak pembelajaran inkuiri yang menjadi rambu-rambu penyusunannya.

\section{METODE PENELITIAN}

Jenis penelitian yang dilakukan adalah penelitian pengembangan (Research and Development). Menurut [7] penelitian pengembangan adalah suatu proses dan langkah-langkah untuk mengembangkan suatu produk baru atau menyempurnakan produk yang telah ada. Dalam hal ini dikembangkan suatu modul Fisika SMA/MA dan SMK dengan menggunakan model inkuiri. Penelitian pengembangan yang dilakukan mengacu pada model pengembangan perangkat pembelajaran oleh [8] yaitu yang melewati tahapan: (1) investigasi awal (preliminary research), (2) perancangan dan realisasi (prototyping phase), dan (3)uji coba dan 
penilaian (assessment phase).

Kegiatan pengembangan ini dimulai dengan investigasi awal, kemudian merancang dan mengembangkan modul, setelah itu dilakukan uji coba dan penilaian. Dalam jurnal ini yang akan dibahas adalah tahap ketiga untuk melihat praktikalitas modul Fisika SMA/MA dan SMK yang telah diujicobakan.

Sebelum dilakukan uji coba modul terlebih dilakukan perumusan/perancangan terhadap modul. Rancangan ini merujuk pada panduan pengembangan bahan ajar yang dikeluarkan oleh Depdiknas. Dalam perancangan bahan ajar melewati beberapa langkah, antara lain : (1) mengkaji kesesuaian materi yang akan disajikan dalam bahan ajar dengan standar kompetensi dan kompetensi dasar yang terdapat dalam kurikulum, (2) menentukan kedalaman materi dan ruang lingkup bahan ajar, menentukan urutan bahan ajar, (4) menentukan jenis perlakuan yang akan diberikan terhadap bahan ajar, (5) menentukan sumber materi pembelajaran.

Setelah tahap perancangan modul yang dikembangkan selesai, dilakukan perencanaan awal secara keseluruhan. Perencaan awal dilakukan dengan penulisan, penelaahan dan pengeditan modul yang disusun. Perancangan modul pembelajaran dibuat sesuai dengan indikator yang ditatapkan dan berdasarkan format yang disesuaikan dengan kebutuhan peneliti. Setelah itu, dirancang rubrik dan kriteria penskoran penilaian portofolio.

Pada tahap perancangan dilakukan formative evaluation yang meliputi self evaluation, prototyping (expert reviews, one-to-one, dan small group), serta field test. Adapun alur desain formative evaluation seperti ditunjukkan pada gambar 1



Gambar 1. Alur Desain formative evaluation [9]

\subsection{Instrumen Penelitian}

Instrumen yang digunakan 
dalam penelitian adalah lembar praktikalitas. Instrumen praktikalitas berupa lembar observasi angket respon dosen dan angket respon mahasiswa terhadap modul pembelajaran. Angket praktikalitas disusun menggunakan skala Likert dengan 4 pilihan jawaban yaitu: 4 (selalu), 3 (sering), 2 (jarang), 1 (tidak pernah).

\subsection{Analisis Kepraktisan}

Angket respon mahasiswa dan angket respon dosen berkaitan dengan kepraktisan penggunaan modul yang telah dibuat. Analisis praktikalitas dilakukan dengan menggunakan skala likert dengan ketentuan: kurang baik = 1 , cukup baik $=2$, baik $=3$, dan sangat baik $=4$

Perhitungan data nilai akhir hasil angket dianalisis dalam skala (0 - 100) dilakukan dengan menggunakan rumus:

$$
p=\frac{f}{n} \times 100 \%
$$

Keterangan:

$$
\begin{aligned}
& P=\text { nilai praktilakitas } \\
& f=\text { skor yang diperoleh } \\
& \mathrm{n}=\text { skor maksimum }
\end{aligned}
$$

(Dimodifikasi dari [10])

Kategori praktikalitas modul berdasarkan nilai akhir yang didapatkan dapat dilihat pada Tabel 3 .

Tabel 3 Kategori Praktikalitas Modul

\begin{tabular}{cc}
\hline Interval & Kategori \\
\hline $0-20$ & Sangat tidak praktis \\
$21-40$ & Tidak praktis \\
$41-60$ & Kurang praktis \\
$61-80$ & Praktis \\
$81-100$ & Sangat praktis \\
\hline
\end{tabular}

(Dimodifikasi dari [10])

\section{HASIL DAN PEMBAHASAN}

Penelitian yang dilakukan adalah penelitian pengembangan (Research and Development). Dalam hal ini dikembangkan suatu modul pembelajaran fisika SMA/MA dan SMK dengan menggunakan model inkuiri dilihat dari
praktikalitasnya.Penelitian pengembangan yang dilakukan mengacu pada model pengembangan perangkat pembelajaran oleh Plomp

Berdasarkan investigasi awal yang dilakukan terhadap mahasiswa maka dilakukan perancangan modul dengan 
menggunakan model inkuiri. Beberapa tahap yang dihasilkan dalam proses perancangan modul pembelajaran. Modul yang dibuat adalah sebuah bahan ajar yang di tulis dengan tujuan agar mahasiswa dapat belajar secara mandiri tanpa atau dengan bimbingan dosen. Karakteristik modul yang dikembangkan dalam penelitian adalah :

1. Terlebih dahulu diawal modul diberikan deskripsi, petunjuk dan penggunaan modul agar sebelum menggunakan modul mahasiswa lebih terarah dalam belajar
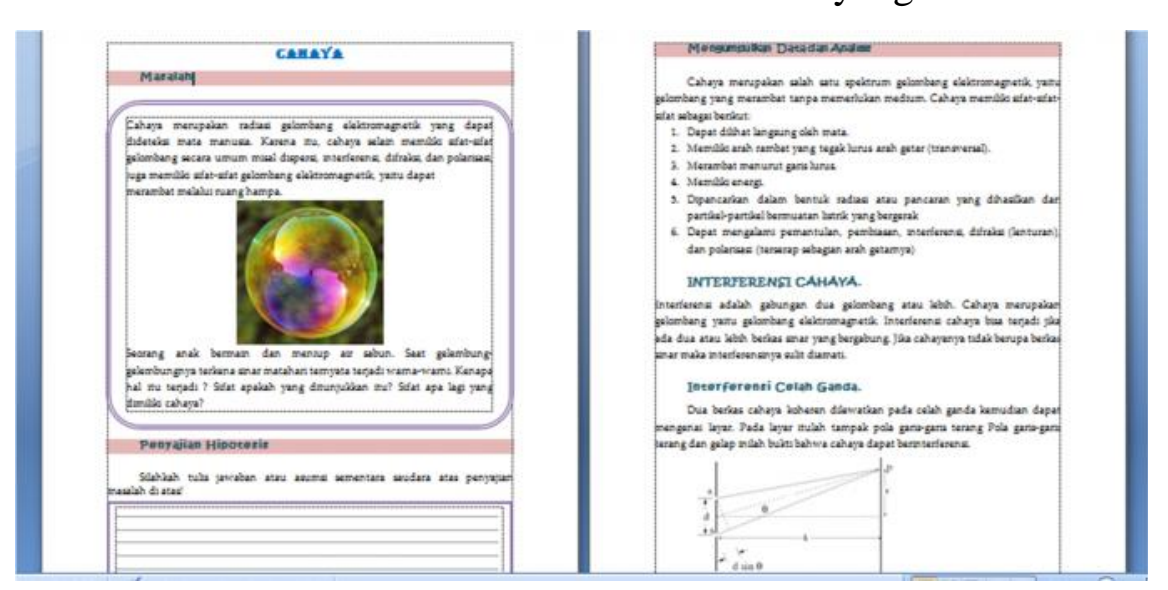

Gambar 3. Rancangan modul berdasarkan sintaks inkuiri

Modul yang telah dirancang selanjutnya di evaluasi dan dinilai oleh pakar atau teman sejawat. Pakar-pakar
Modul berisi petunjuk belajar , kompetensi yang akan dicapai, isi materi, informasi pendukung, evaluasi yang dikaitkan dengan komponen inkuiri yaitu merumuskan masalah, merumuskan hipotesis, mengumpulkan data, dan membuat kesimpulan.

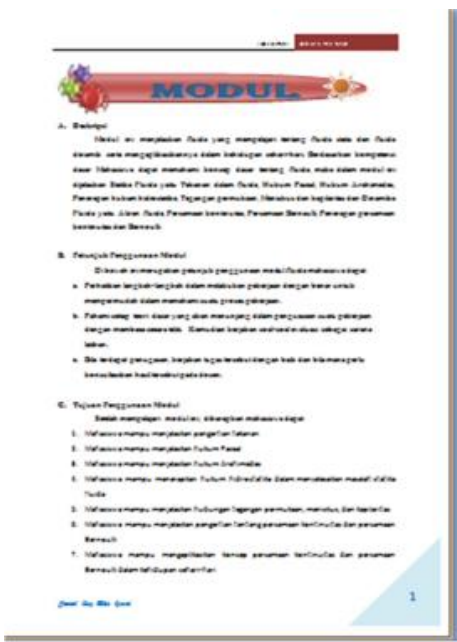

Gambar 2 Rancangan deskripsi, petunjuk dan penggunaan modul

2. Materi yang disampaikan berdasarkan sintaks inkuiri yang ada

tersebut menilai validasi isi, konstruk, dan bahasa. Setelah modul dalam pembelajaran Fisika SMA/MA dan 
SMK berbasis Inkuiri dinyatakan valid maka dilakukan uji coba untuk melihat praktikalitas modul.

Praktikalitas modul dilihat dari sejauh mana dosen dan mahasiswa dapat menggunakan modul dalam pembelajaran Fisika SMA/MA dan SMK berbasis Inkuiri pada materi gelombang. Untuk melihat apakah perangkat pembelajaran yang telah dibuat praktis digunakan atau sebaliknya, maka dilakukan uji coba pada mahasiswa. Praktikalitas modul dapat dilihat daril angket kepraktisan yaitu angket respon mahasiswa dan angket respon dosen yang diberikan di akhir pertemuan.

Hasil pengolahan praktikalitas modul oleh dosen dan mahasiswa dapat dilihat pada Tabel 4.

Tabel 4. Hasil Praktikalitas Modul (Respon Dosen)

\begin{tabular}{ccc}
\hline Dosen & Jumlah (\%) & Kesimpulan \\
\hline AH & $81,9 \%$ & Sangat praktis \\
AR & $86,3 \%$ & \\
\hline
\end{tabular}

Hasil praktikalitas modul yang terlihat pada Tabel 4 adalah sangat praktis dengan rata-rata nilai persentase adalah $84,1 \%$. Dengan demikian respon dosen terhadap modul adalah sangat praktis.

Praktikalitas adalah tingkat keterpakaian prototipe perangkat pembelajaran oleh dosen dan mahasiswa, yaitu melaksanakan pengajaran dengan menggunakan perangkat pembelajaran yang telah direvisi berdasarkan penilaian validator. Dosen dan mahasiswa mengisi angket kepraktisan, dan di analisis sehingga dapat diketahui tingkat kepraktisan modul yang digunakan. Selain itu, peneliti menggunakan lembar observasi keterlaksanaan terhadap dosen dan mahasiswa.

Berdasarkan hasil analisis angket kepraktisan dari dosen didapatkan modul berkategori sangat praktis, hal ini terlihat dari persentase tanggapan dosen terhadap modul adalah $84,1 \%$. Berdasarkan hasil analisis terhadap angket respon dosen menunjukkan bahwa modul yang telah dikembangkan praktis digunakan dalam pembelajaran. Ini terlihat dari hasil analisis angket yang berkategori sangat praktis. Dosen menyatakan bahwa modul pembelajaran tersebut berbeda dari yang telah ada dan praktis untuk digunakan.

\section{KESIMPULAN}

Berdasarkan pengembangan dan uji coba modul Fisika SMA/MA dan SMK menggunakan Inkuiri pada materi gelombang yang dilengkapi penilaian portofolio yang telah dilakukan, diperoleh kesimpulan modul Fisika SMA /MA dan SMK berbasis Inkuiri pada materi gelombang yang dilengkapi 
penilaian portofolio yang dikembangkan ini berkategori praktis dilihat dari angket respon dosen dan mahasiswa.

\section{SARAN}

Peneliti hanya mengambil lingkup kecil sebagai uji coba modul. Untuk mendapatkan hasil yang lebih maksimal sebaiknya diambil lingkup yang lebih luas untuk uji coba modul yang dibuat. Perangkat pembelajaran fisika dengan menggunakan model Inkuiri dapat dikembangkan oleh dosen pada materi dan konsep lainnya karena dapat membantu terciptanya pembelajaran yang interaktif, menantang, menyenangkan dan memotivasi mahasiswa untuk berpartisipasi aktif dan kritis serta inovatif dalam kegiatan pembelajaran.

\section{UCAPAN TERIMA KASIH}

Ucapan terimakasih kepada

Kementrian Riset, Teknologi dan Pendidikan Tinggi Direktorat Jenderal Penguatan Riset dan Pengembangan atas bantuan dana penelitian.

\section{DAFTAR PUSTAKA}

[1] Mulyasa, 2008, Kurikulum Tingkat Satuan Pendidikan (KTSP),
Remaja Rosda Karya,
Bandung.

[2] Badan Standar Nasional Pendidikan, 2007, Panduan Penilaian Kelompok Mata Pelajaran Ilmu Pengetahuan dan Teknologi, Departemen Pendidikan Nasional, Jakarta:.

[3] Trianto, 2007, Model-model Pembelajaran Inovetif Berbasis Konstruktifistik, Prestasi Pustaka, Jakarta.

[4] Roestiyah, 2012, Strategi Belajar Dan Mengajar, Rineka Cipta, Jakarta

[5] Depdiknas, 2004, Pedoman Pengembangan Portofolio untuk Penilaian, Depdiknas, Jakarta.

[6] Depdiknas, 2008, Panduan Pengembangan Bahan Ajar, Depdiknas, Jakarta.

[7] Sudjana, N 2002, Penilaian Proses Hasil Belajar Mengajar, Remaja Rosdakarya, Bandung

[8] Plomp, T, 2010, An Introduction to Educational Design Research, University of Twente, Enschede.

[9] Tessmer, M, 1998, Planning and Conducting Formative Evaluations, Kogan Page, Philadelphia.

[10] Riduan, 2009, Belajar Mudah Penelitian untuk Dosen, Karyawan dan Peneliti Muda, Alfabeta, Bandung. 